\title{
The content of the concept "quality of education" and the definition of methods to measure it
}

\author{
Alexey Ryzhov ${ }^{1 *}$, Konstantin Ziskin ${ }^{2}$, Polina Razumovskaya ${ }^{1}$, Valery $_{\text {Umyarov }}{ }^{3}$, and \\ Dmitry Peshcherov ${ }^{4}$ \\ ${ }^{1}$ Moscow Pedagogical State University, Institute of Pedagogy and Psychology, Department of \\ Pedagogy and Psychology of Professional Education named after V.A. Slastenin, Moscow, Russia \\ ${ }^{2}$ Lomonosov Moscow State University, Center for Educational Development Strategy, Moscow, \\ Russia \\ ${ }^{3}$ College 26 of Architectural Design and Engineering, Structural Unit 8, 13, Moscow, Russia \\ ${ }^{4}$ Moscow Pedagogical State University, Institute "Higher School of Education", Moscow, Russia
}

\begin{abstract}
The concept "quality of education" is widely used in modern educational practice; however, in teaching, there is no common understanding of the pedagogical phenomenon that underlies this concept. In this regard, it is necessary to present reflections on the content of such terms as "education" and "quality" in relation to the cultural and historical prerequisites for the formation of the category "quality of education" and various approaches to its content. Besides, the article touches upon different approaches to the procedures for measuring the quality of education and distinguishes their strengths and weaknesses. The authors encourage the reader to think about the problems of defining the quality of education as a pedagogical phenomenon in modern conditions through cultural and historical traditions. The study results in the consideration of various aspects of the evolution of such terms as "quality" and "education" in Russian pedagogy, which have influenced the modern interpretations of the concept "quality of education" and the approaches to its measurements. The article reveals the advantages of a practical understanding of the quality of education, as well as the risks associated with the transformation of education into a service and the absolutization of its quantitative parameters in measuring the quality of education. The authors raise the questions that remain open and require their solution despite the continued interest in the problems of education quality in pedagogical theory and practice. The novelty of the research is provided by taking into consideration Russian cultural and historical traditions of the formation of such terms as "education" and "quality" and the justification of the possible ways of their use in modern approaches to the measurements of quality of education, as well as the justification of the importance of using the applied aspect of the quality of education in Russian educational practice.
\end{abstract}

Keywords: history of terminology, quality of education, measurement of quality of education, education as a service.

${ }^{*}$ Corresponding author: ranik2006@yandex.ru 


\section{Introduction}

The concept "quality of education" has recently been established in the scientific and pedagogical vocabulary. The problems devoted to the quality of education are considered both at the level of a particular educational institution, on a national scale, and even at the international level. These problems include measuring the quality of education, improving the quality of education, establishing quality standards, and so on. The quality of education as a certain result of pedagogical activity undergoes several different measurements. Their results heavily influence the revision of the activities of teachers and heads of educational institutions that work in the field of organizing and shaping the content of education and forms and methods of teaching. Despite the importance attached to assessments and measurements of the quality of education, this concept is quite controversial. During the study, we examined the concepts of "quality" and "education" from the historicalpedagogical and cultural-historical points of view and identified various aspects of the use of the notion "quality of education" in solving pedagogical problems.

\section{Methods}

Since the conducted research is to a great extent of a historical and pedagogical nature, we singled out the main groups of sources devoted to the research problem:

- historical and pedagogical documents and studies that allow tracing the evolution of such terms as "quality" and "education", as well as their semantic transformation, which made it possible to use the concept of "quality of education";

- normative documents and analytical materials on various aspects of measuring the quality of education in Russia and abroad: the UNESCO Convention of December 14, 1960, in which the concept "quality of education" was first formulated [1], "General Agreement on Trade in Services" (GATS, 1994 and 2000), the European Council Resolution on Lifelong Learning (2002), the international program of the same name, and some others;

- modern analytical studies devoted to the problems of the quality of education and the methods and forms of its measurement. First of all, these are the works of the Centre of Assessing the Quality of Education of the Institute for Education Development Strategy, Russian Academy of Education.

\section{Results}

The key relevance of the study is in the consideration of the evolution of such terms as "education", "quality", and "quality of education" and the influence of this evolution on the transformation of the pedagogical phenomenon underlying the quality of education.

The appearance in the Russian language of the word "education" refers to the 11th-12th centuries. It was the period of the formation of the Slavic language, the spread of writing and Christianity, and, as a result, the adoption of a certain system of values, where the goal of education was to bring each person closer to the image and likeness of God [2].

In several European languages, the word "education" comes from the Latin "education", which meant "to educate, cultivate, lead". The formation of these languages also took place simultaneously with the spread of Christianity; therefore, up to the 18th century both in Russian and many European languages, the concept of "education" had the same content, including the issues of both instruction and education.

Under the influence of the ideas of the Enlightenment, which were, first of all, atheistic and social, the content of the concept of "education" changed. It began to mean correspondence to a certain pattern developed by a community or a person [3]. At the same time, the value and educational component continued to be an important part of education. 
At the beginning of the 19th century, the state unitary education systems began to actively develop in Russia and Germany, and by the middle of the century, the process had started in Europe. In most European countries and the United States, the leading goal was the elimination of illiteracy associated with the need to involve a large number of the population in qualified economic activities [4]. The content of education in most of the developed capitalist countries of that time was based on Protestant ethics (according to M. Weber), the national ideology, and the results of scientific and technological changes in the late 19th and early 20th centuries. Russia was, perhaps, the only exception, since, unlike in Western European countries, Orthodoxy continued to influence the state's policy in the educational sphere. For the examined problem, this historical period is important, because this is the period when the first national education standards appeared.

The 1990s-2000s were marked by the Russian education system's serious shift away from the traditional scale of values that had developed over centuries. Instead, it adopted a whole range of so-called "democratic freedoms" in the context of a new value system, according to which everyone was free to live in one's special system of values.

During the study, we justified the need to talk about at least two sides of the concept of "quality of education" and showed a very fragile connection between the terms "quality" and "education". If we consider "quality" to be the satisfaction of needs and the level of compliance with a norm or requirement [5], then an object (in our case, it is education), which does not correspond to them, does not have quality; therefore, the given object does not exist. On the other hand, the satisfaction of the requirements and needs of a person in the educational process is present, but they can appear after 5, 10, 20, and so on years. Moreover, education always has a delayed result. If it is not in demand now in certain conditions, this does not mean that it is useless. Indeed, is it possible today to formulate the answer to the question: is it necessary to read, for example, F.M. Dostoevsky? What is the use for it for workers?

A correlation between the two meanings of the concepts "quality" (an essential feature and correspondence to certain norms) and "education" (a person's image and an educational service) is established easily, which allows us to talk about two possible interpretations of the quality of education. In a general sense, the quality of education is the acquired image of a person, which determines the uniqueness and proves the person's moral growth. In this sense, the quality of education is an extremely subjective characteristic that is difficult to measure objectively. In the learning process, even individual, a person assimilates information based on an already existing system of values, personal moral norms, and worldview. Their nature is subjective and determines the logic of the formation of knowledge, abilities, and skills (competencies). As a result, each person develops a certain idea of the quality of education. We are convinced that the quality of education in its general sense is practically impossible to manage since it depends on many different influences. Government structures can only assess the quality of the provided information, the effectiveness of the forms and means of its development, etc. Thus, it can be noted that the content of the term "quality" is internationally universal, and the term "education", which has developed in the Russian language, does not have such a character.

It is very difficult to quantify human education. Many modern international programs are focused not on the measurements of the quality of education, but the assessment of general educational and subject literacy [6]. However, can functional literacy and education be equated? Let us try to answer this question with the help of referring to historical examples.

In the 17th century, the master Alexander Grigorievich Lykov was working at the Pushkarsky Dvor in Moscow. By the age of 19 he had cast the largest bell in the world: the Great Uspensky Bell of the Moscow Kremlin. The name of the master was also on other famous bells. According to the documents, this master was illiterate, but had perfect knowledge in the field of mathematics, geometry, metallurgy, the strength of materials, and 
the skills of reading drawings [7]. The above-mentioned example shows that the lack of writing skills does not indicate a lack of education and vice versa.

The next example is from Western Europe. In France, in the 1980s-1990s, a significant number of people who graduated from primary and secondary school were unable to read even simple newspaper articles after a while [8]. They preferred watching television programs. Several scientists identified the drawbacks of education and the growth of illiteracy. However, in the end, the solution to the problem was found in a "new" phenomenon called "illiteratus" (Latin "illiteratus" - non-perception of the text). At the same time, the statistics of education continued to take into account only those who were illiterate "in fact", or, in other words, those who did not graduate from school.

\section{Discussion}

On the one hand, the quality of education as a special personal characteristic, which cannot be reduced to individual learning results, is potentially immeasurable. On the other hand, the quality of educational services and the effectiveness of the education system can and should be assessed.

In recent years, a new direction of science, pedagogical qualimetry, has been intensively developing, and new control and evaluation procedures are being developed to ensure the reliability of educational information [9-10]. Statistical methods are being adapted to the field of educational research. The process of measuring students' educational achievements is extremely standardized; complex formulas are used to guarantee the effectiveness of the tests and the objectivity of processing their results. The all-Russian system for assessing the quality of education is formed using worldwide experience. Close attention is paid to international programs such as TIMSS, PIRLS, and PISA.

Understandably, supporters of the qualimetric approach strive to give an objective picture of the education system development, create a reliable measurement technology based on statistical methods and rigorous mathematical calculation, standardize the quality of education, and create a supranational system of its indicators [11-12]. Yet, the quality of the result does not always correspond to the quality of the process and vice versa. With the help of formalized criteria, it is possible to characterize the personnel potential: work experience, academic degree, number of publications, etc. [13-15]. However, we wonder if they always guarantee the quality of work.

What is more important, being carried away by the applied characteristics of the quality of education, we lose its moral foundations. In the field of education, non-standardized elements are of particular importance, for example, the hidden desires of people, sometimes elusive even for themselves, but controlling their thoughts, actions, and behavior. In most cases, neither an oral exam nor a test can help to find out, for example, why a particular student is hard working. We are convinced that when pedagogical interaction within education is built based on values, the understanding of the quality of education, in general, will change. In this case, all measurements will either become more productive or there will be no need for them.

\section{Conclusion}

The results of the study made it possible to conclude that the possibilities of various procedures for measuring the quality of education used in educational practice cannot be absolute. Any objective indicators of the quality of education should be considered conditional since it is impossible to express the quality either of education in general or of any its components with a precise number, even taking into account permissible errors. It is 
not possible to use methods that are applicable in production, business, and other areas even after changing the subject of standardization (we are not talking about the "quality of a person", but about the quality of an educational program and service). It is important to realize that, first of all, it is the person, and not the teacher or employer, who needs the measurements of the quality of education.

\section{References}

1. UNESCO, Convention against Discrimination in Education, 1960. Article 4, ED/2003/CONV/H/1 (UNESCO, Paris, 2003)

2. A.N. Ryzhov, Voprosy Obrazovaniya [Educational Studies Moscow], 4, 217-237 (2008)

3. I. Kant, Chto takoe prosveshchenie [Answering the Question: What Is Enlightenment?] (CHORO Publ., Moscow, 1994)

4. W. Harnisch, Ausführliche Darstellung und Beurteilung des Bell-Lancasterschen Schulwesens in England und Frankreich [Detailed description and assessment of the Bell-Lancaster school system in England and France] (bei Grass, Barth und Comp., Breslau, 1819)

5. Natsionalnyi standart Rossiiskoi Federatsii sistemy menedzhmenta kachestva. Trebovaniya [National Standart of the Russian Federation for the quality management systems. Requirements] (Standartinform, Moscow, 2020)

6. G.S. Kovaleva, A.Y. Pentin, E.I. Davydova, Voprosy Obrazovaniya [Educational Studies Moscow], 1, 79-109 (2018). https://doi.org/10.17323/1814-9545-2018-1-79109

7. V.I. Afanasiev, Dokumentalnyye materialy XVII veka o liteynom proizvodstve v Rossii v "Osnovnom sobranii gramot" [Documentary materials from the 17th century about foundries in Russia in "Basic collection of letters"], in Problemy istochnikovedcheskogo izucheniya rukopisnykh i staropechatnykh fondov [Problems of source study of handwritten and early printed funds] (Izdatel'stvo Rossiyskoy natsional'noy biblioteki, Leningrad, 1979)

8. K. Kuno, Chtenie vo Frantsii [Reading in France] (Rudomino, Moscow, 1992)

9. G.S. Kovaleva, Vestnik Obrazovaniya Rossii [Bulletin of education of Russia], 14, 4952 (2019)

10. G.A. Tsukerman, G.S. Kovaleva, V.Yu. Baranova, Voprosy obrazovaniya [Educational Studies Moscow], 1, 58-78 (2018). https://doi.org/10.17323/1814-9545-2018-1-58-78

11. V.A. Bolotov, Voprosy Obrazovaniya [Educational Studies Moscow], 3, 287-297, (2018). https://doi.org/10.17323/1814-9545-2018-3-287-297

12. G.S. Kovaleva, Vestnik obrazovaniya Rossii, 16, 32-36 (2019)

13. O.V. Mikhailov, Vysshee obrazovanie v Rossii [Higher Education in Russia], 10(205), 71-78 (2016). https://vovr.elpub.ru/jour/article/view/862

14. D.G. Sandler, A.D. Sushchenko, Universitetskoe upravlenie: praktika i analiz [University Management: Practice and Analysis], 3, 73-85 (2018). https://doi.org/10.15826/umpa.2018.03.028

15. L.V. Konstantinova, Vysshee obrazovanie v Rossii [Higher Education in Russia], 29, 8-9 (2020). https://vovr.elpub.ru/jour/article/view/2396 